\title{
Petrology, age, and tectonic setting of The Wolves Pluton: implications for Appalachian terranes in the western Bay of Fundy region
}

\author{
Heather A. Wolczanski ${ }^{1^{*}}$, Sandra M. Barr ${ }^{1 \dagger}$, And Brent V. Miller ${ }^{2}$ \\ 1. Department of Geology, Acadia University, Wolfville, Nova Scotia B4P 2R6, Canada \\ 2. Department of Geology and Geophysics, Texas A\&M University, College Station, Texas 77843-3115, USA \\ ${ }^{\dagger}$ Corresponding author: <sandra.barr@acadiau.ca $>$ \\ * Present address: Department of Geological Sciences and Geological Engineering, \\ Miller Hall, Queen's University, Kingston, Ontario K7L 3N6, Canada
}

Date received: 23 December 2006 Date accepted: 17 April 2007

\begin{abstract}
The islands known as The Wolves are located in the Bay of Fundy, approximately $10 \mathrm{~km}$ offshore from mainland southwestern New Brunswick. They are underlain by monzodiorite, gradational to diorite, quartz diorite, and quartz monzodiorite, and minor units of tonalite and quartz monzonite, herein termed collectively The Wolves Pluton. Finer grained dioritic xenoliths are abundant in all the units. Rare syenite dykes and scattered mafic dykes intrude the pluton. Samples from the monzodiorite unit have silica concentrations ranging from 47.6\% to 59.6\% (average $54.5 \%$ ), whereas tonalite samples have higher $\mathrm{SiO}_{2}$ from $65.4 \%$ to $73.3 \%$ (average $69.6 \%$ ) and two quartz monzonite samples have about $69 \% \mathrm{SiO}_{2}$. Although finer grained, the xenoliths are generally similar in mineralogy and chemical composition (49.2-54.7\% $\mathrm{SiO}_{2}$ ) to the dioritic part of the monzodiorite unit. Based on continuity and similarity of chemical trends and patterns, the monzodiorite, tonalite, and quartz monzonite, as well as the dioritic xenoliths, are interpreted to be co-magmatic. They constitute a calc-alkalic, I-type granitoid suite that likely formed in a subduction zone. A sample of monzodiorite from East Wolf Island yielded an Early Silurian U-Pb age of $436.4 \pm 1.2 \mathrm{Ma}$, showing that The Wolves Pluton is not related to the Late Neoproterozoic to Early Cambrian plutonic rocks of the Caledonia, Brookville, and New River terranes, or of Grand Manan Island. They are older than Late Silurian-Devonian plutons of the Coastal Maine Magmatic Province. The best match in age is with Lower Silurian volcanic and granitic units of the Kingston terrane, although the rocks of The Wolves Pluton differ petrologically from the mainly fine-grained granite typically exposed in the Kingston terrane. Nevertheless, the similarity in age and inferred tectonic setting, as well as their similar positive epsilon Nd signatures, suggest that The Wolves Pluton might represent a deeper part of the Kingston volcanic arc. If so, the location of The Wolves Pluton apparently necessitates sinistral offset of the Kingston terrane to the southeast.
\end{abstract}

\section{RÉSUMÉ}

Les îles appelées The Wolves sont situées dans la baie de Fundy, à une dizaine de kilomètres au large de la partie intérieure du Sud-Ouest du Nouveau-Brunswick. Elles reposent sur une unité de jotunite passant graduellement à de la diorite, de la diorite quartzique et de la jotunite quartzique, accompagnée d'une unité secondaire de tonalite et d'adamellite, collectivement appelées dans le présent résumé le pluton The Wolves. Les xénolites dioritiques à grains plus fins sont abondants dans toutes les unités. De rares dykes syénitiques et des dykes mafiques dispersés pénètrent le pluton. Les échantillons de l'unité de jotunite renferment des concentrations de silice variant entre 47,6\% et 59,6\% (en moyenne 54,5\%), tandis que les échantillons de tonalite comportent des concentrations supérieures de $\mathrm{SiO}_{2}$ variant entre $65,4 \%$ et $73,3 \%$ (en moyenne $69,6 \%$ ) et que deux échantillons d'adamellite renferment environ $69 \%$ de $\mathrm{SiO}_{2}$. Même si les xénolites présentent des grains plus fins, ils ont généralement une composition minéralogique et chimique similaire (49,2 à 54,7\% de $\mathrm{SiO}_{2}$ ) à la partie dioritique de l'unité de jotunite. S'appuyant sur la continuité et la similarité des tendances et des configurations chimiques, on interprète la jotunite, la tonalité et l'adamellite, tout comme les xénolites dioritiques, en tant qu'éléments comagmatiques. Ils constituent un cortège granitique de type intrusif, calco-alcalin, qui s'est probablement formé dans une zone de subduction. Un échantillon de jotunite de l'île East Wolf a donné par datation U-Pb un âge du Silurien précoce de 436,4 \pm 1,2 Ma, ce qui révèle que le pluton The Wolves n'est pas apparenté aux roches plutoniques du Néoprotérozoïque tardif au Cambrien précoce des terranes de Caledonia, de Brookville et de New River ni à l'île Grand Manan. Les îles sont plus âgées que les plutons du Silurien 
tardif au Dévonien de la province magmatique de la côte du Maine. Le meilleur jumelage possible selon l'âge est celui avec les unités volcaniques et granitiques du Silurien inférieur du terrane de Kingston, même si les roches du pluton The Wolves diffèrent du point de vue pétrologique du granite essentiellement à grains fins typiquement dénudé dans le terrane de Kingston. La similarité de l'âge et le cadre tectonique présumé, ainsi que leurs signatures epsilon $\mathrm{Nd}$ positives similaires, laissent supposer que le pluton The Wolves pourrait représenter une partie plus profonde de l'arc volcanique de Kingston. Le cas échéant, l'emplacement du pluton The Wolves nécessite apparemment un décalage senestre du terrain de Kingston vers le sud-est.

\section{[Traduit par la redaction]}

\section{INTRODUCTION}

The Wolves are a group of small rocky islands located in the Bay of Fundy, approximately $10 \mathrm{~km}$ offshore from southwestern New Brunswick (Fig. 1). Alcock (1948) described the rocks on the islands as "reddish granite", whereas Ritchie(1985) mapped the largest island (East Wolf) as medium-grained, pinkish hornblende-biotite granodiorite. A positive aeromagnetic anomaly extends $\sim 500 \mathrm{~m}$ offshore from the islands and closely follows the shape of the island group (Geological Survey of Canada 1965a, b), suggesting that the granitoid rocks outcropping on the island are part of a larger pluton with an area of about $75 \mathrm{~km}^{2}$.

The Wolves are located in an area where the Caledonia, Brookville, and Kingston terranes of southern New Brunswick extend into the offshore, and where major terrane-bounding faults, including the offshore extension of the CobequidChedabucto fault zone between Avalonia and Meguma, appear to converge (Fig. 1). Barr et al. (2001) included The Wolves in the Brookville terrane, based on their location on trend with that terrane (Fig. 1) and on a reconnaissance examination of the rocks on the islands which suggested that they are similar to the ca. 555-525 Ma granitoid rocks typical of the Brookville terrane. Barr et al. (2001) used the inferred correlation to justify extending the Brookville terrane an additional $30 \mathrm{~km}$ into the Bay of Fundy. However, a preliminary U-Pb age of ca. 440 Ma subsequently reported by Barr et al. (2003a) indicated that some, if not all, of the plutonic rocks on The Wolves are Silurian, and hence unlikely to be linked to the NeoproterozoicCambrian plutons of the Brookville terrane.

In this paper we report the results of a petrochemical study of the granitoid rocks, herein named The Wolves Pluton, which make up The Wolves, and confirm the preliminary U-Pb age cited by Barr et al. (2003a). We use these data to infer a terrane affiliation for The Wolves Pluton and discuss implications for terrane configuration in the Bay of Fundy.

\section{FIELD RELATIONS AND PETROGRAPHY}

Outcrops and field relationships on The Wolves were observed during three one-day mapping and sampling boat excursions in 2000, 2004, and 2005. Most of the islands consist of grey to pink, medium- to coarse-grained granitoid rocks that are assigned here to a compositionally variable unit in which monzodiorite is the main component (Fig. 2). Two other rock units form small areas on the islands: tonalite on the southern third of South Wolf Island and on a small promontory on the southeastern shore of East Wolf Island, and quartz monzonite on Spruce Island (Fig. 2). All three units contain abundant dioritic xenoliths. A swarm of small syenitic dykes up to $\sim 1$ $\mathrm{m}$ in width occur in monzodiorite on Green Rock, and scattered mafic dykes up to $5 \mathrm{~m}$ wide were observed mainly on the southern coast of East Wolf Island.

Based on modal analysis of twenty samples, the monzodiorite unit varies from diorite through quartz diorite, monzodiorite, and quartz monzodiorite (Fig. 3). The rocks locally show magmatic layering that results from alternating changes in the proportion of felsic and mafic minerals, a feature especially well developed in some outcrops on the northwestern shore of East Wolf Island (Fig. 4a). The layering trends approximately east-west, and dips steeply to the south; cross-cutting relations suggest that the top of the pluton may be to the south, but data are too localized to attach much significance to that observation. Plagioclase, biotite, and amphibole are the most abundant minerals in the monzodiorite unit (Figs 5a, 6a). Interstitial quartz and potassium feldspar (orthoclase) form up to $30 \%$. The amphibole commonly contains relict cores of clinopyroxene. Accessory minerals include abundant apatite, magnetite, zircon, and large sub- to euhedral grains of titanite. On the southern islands, the rocks are more altered, with feldspars increasingly saussuritized and sericitized, and the mafic minerals increasingly altered to chlorite, epidote, and actinolite.

Based on electron microprobe analyses tabulated in Wolczanski (2006), plagioclase compositions in the monzodiorite unit vary from labradorite to oligoclase $\left(\mathrm{An}_{56}\right.$ to $\left.\mathrm{An}_{20}\right)$. Biotite is intermediate in composition between phlogopite and annite, with $\mathrm{Fe} /(\mathrm{Fe}+\mathrm{Mg})$ of about 0.4 to 0.5 . On the $\mathrm{MgO}$ $\mathrm{FeO}-\mathrm{Al}_{2} \mathrm{O}_{3}$ ternary discrimination diagram of Abdel-Rahman (1992), the biotite compositions plot in the field of biotite in calc-alkaline orogenic suites. Amphibole is mainly magnesiohornblende to actinolitic hornblende (classification of Leake et al. 1997). Relict clinopyroxene cores in the amphibole include both low-Ca (augite) and high-Ca (diopside) varieties, both with Fe to $\mathrm{Mg}$ ratio of about 0.2 to 0.3

The tonalite on East Wolf and South Wolf islands consists of plagioclase, quartz, and interstitial biotite with little to no amphibole or K-feldspar (Figs. 3, 5b, 6b). The tonalite differs in texture from the monzodiorite in that it is coarse grained, and quartz is not interstitial but instead forms large anhedral crystals (Fig. 5b, 6b). The contact between monzodiorite and tonalite on East Wolf Island is not exposed, but on the west- 


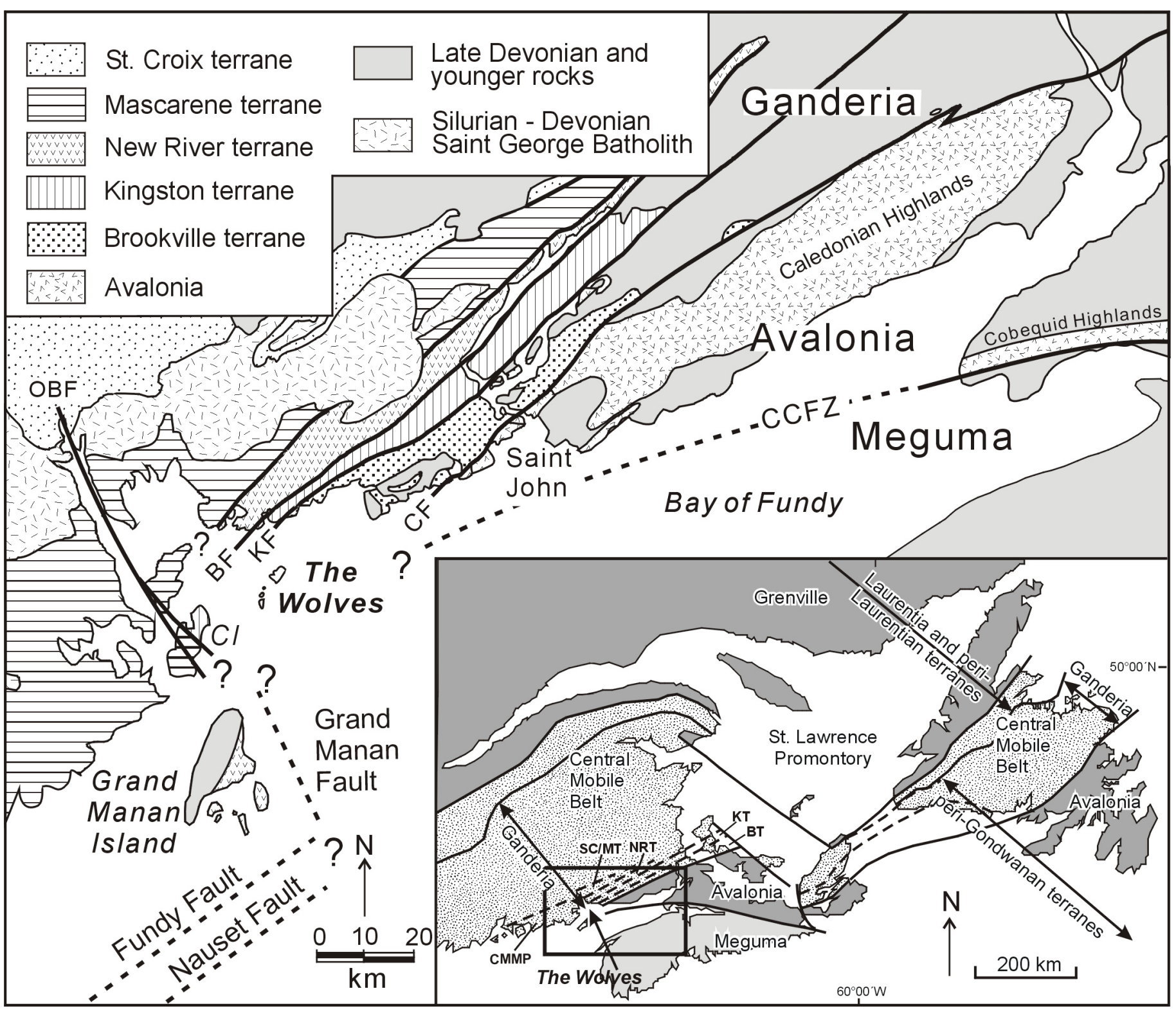

Fig. 1 Terranes in the Bay of Fundy region (after Hibbard et al. 2006) showing the location of The Wolves. Abbreviations: BF, Belleisle Fault; BT, Brookville terrane; CCFZ, Cobequid-Chedabucto fault zone; CF, Caledonia Fault; CI, Campobello Island; CMMP, Coastal Maine magmatic province; KF, Kennebecasis Fault; KT, Kingston terrane; NRT, New River terrane; OBF, Oak Bay Fault; PB, ; SC/MT, St. Croix and Mascarene terranes.

ern shore of South Wolf Island the relationship appears to be gradational, with a southward increase in grain size and quartz content from the monzodiorite to tonalite over a distance of several tens of metres.

The third unit on The Wolves, quartz monzonite, was mapped along the western part of Spruce Island and, based on reconnaissance views from the boat, appears to form the whole island. The quartz monzonite is pink and coarse grained (Fig. $5 c$ ) and consists of plagioclase, microcline, interstitial quartz, biotite, and hornblende with augite cores (Fig. 3, 6c). The plagioclase has been saussuritized and the biotite displays alteration to chlorite. Accessory phases include apatite, titanite, and magnetite. At one location on the west side of Spruce Island, the quartz monzonite has been intruded by a $\sim 5 \mathrm{~m}$-wide dyke of monzodiorite (Fig. 4b). The contact between the two units is sharp but irregular, and rounded xenoliths of quartz monzonite are present in the monzodiorite dyke. These relationships suggest that the quartz monzonite may not have been completely crystallized when intruded by the monzodiorite magma. Both units also contain abundant and similar dioritic xenoliths.

The monzodiorite and tonalite units on South Wolf Island have locally developed foliation defined by alignment of mafic minerals and/or elongate quartz grains. The foliation trends northeast to east with mainly steep dips to the southeast and south. Localized brittle shear zones occur on all the islands and generally trend east-northeast with varying dips from shallow 


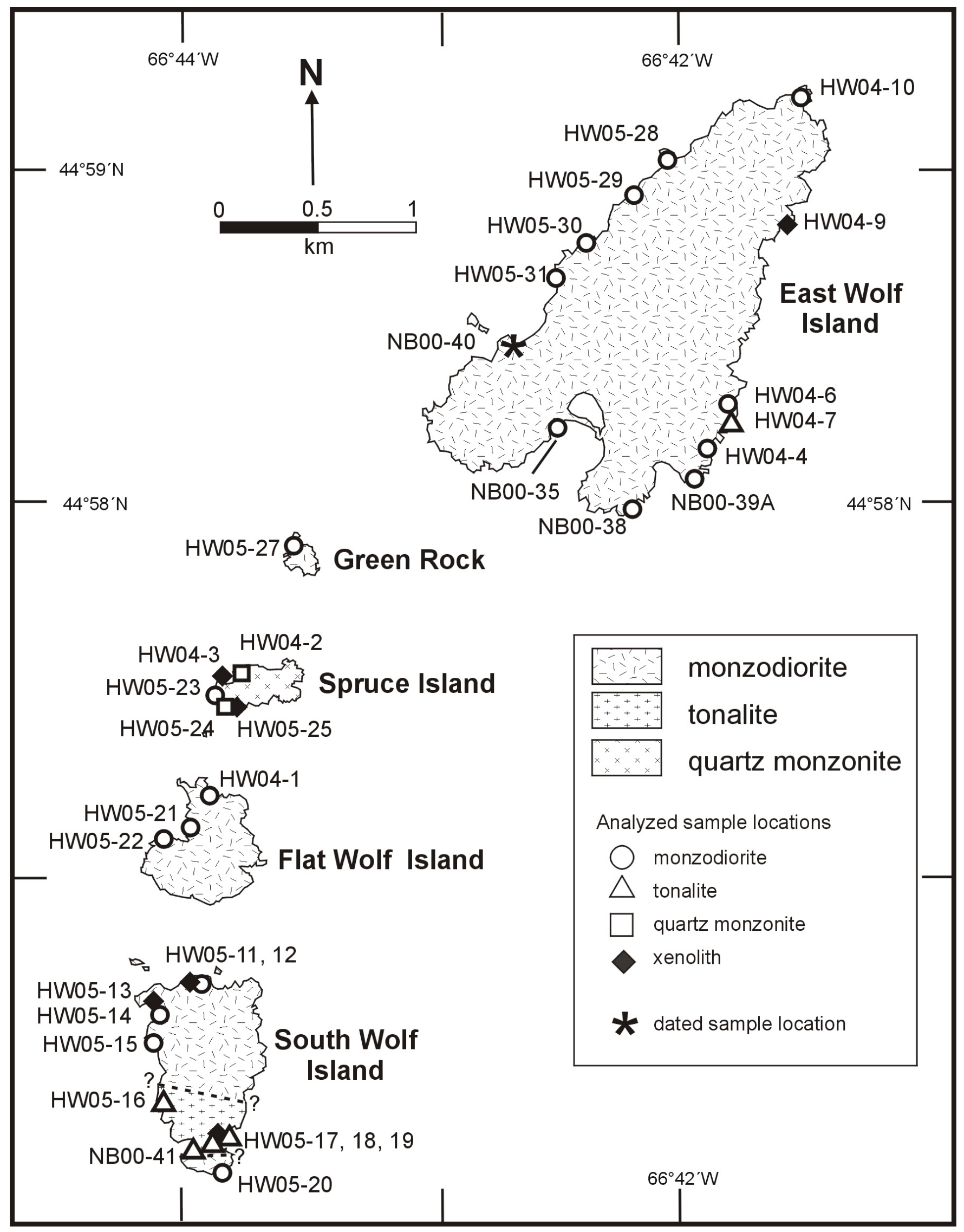

Fig. 2 Geological map of The Wolves based on the present study. Sample locations are indicated by symbols. 


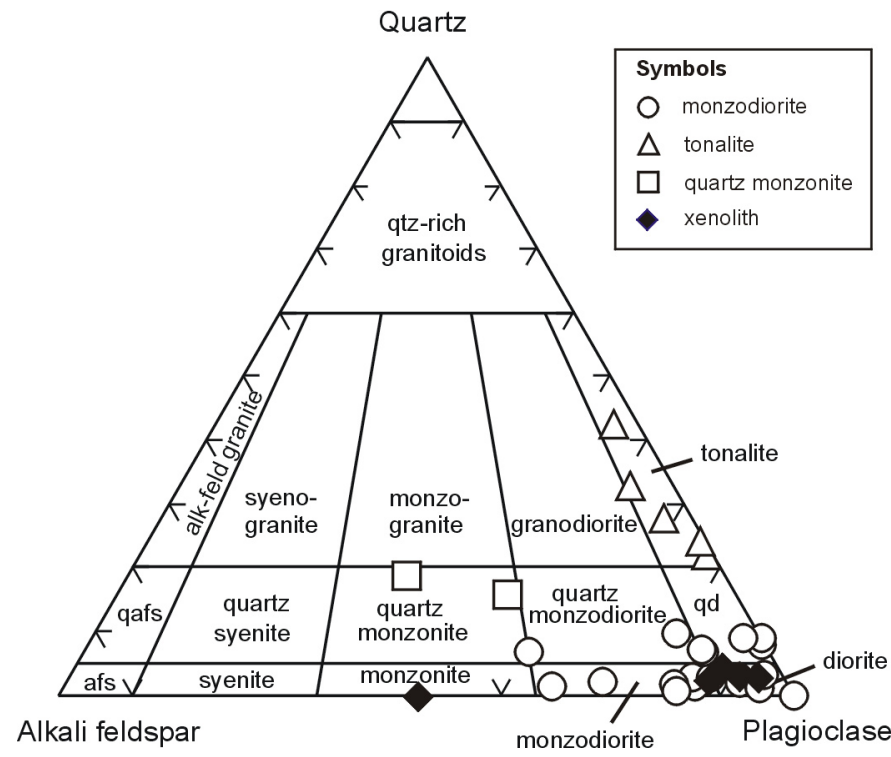

Fig. 3 Modal mineralogy of samples from The Wolves plotted on the Q (quartz) - A (alkali feldspar) - P (plagioclase) ternary diagram with fields from Streckeisen (1976). Data were obtained by counting of approximately 200 points on slabs etched in hydrofluoric acid and stained for K-feldspar following the method of Hutchinson (1974), combined with visual estimates of fine-grained components in thin section.

to steep. No evidence for south-dipping thrust or normal faults as seen in southern New Brunswick (King and Barr 2004; Nance 1987; Park 2001) and in offshore seismic reflection profiles (Keen et al. 1991) was observed on the island.

Dark grey xenoliths are common in the monzodiorite, tonalite, and quartz monzonite units. They are commonly ovoid and $15-20 \mathrm{~cm}$ long, although at one location on South Wolf Island some xenoliths are more than $1 \mathrm{~m}$ across. Texture is fine- to very fine-grained, hypidiomorphic inequigranular to granular (Figs. 5d, 6d). The xenoliths consist of plagioclase, biotite, magnesio-hornblende with relict cores of clinopyroxene, and interstitial quartz and potassium feldspar (Fig. 6d). They range from diorite to monzodiorite, with the exception of one sample (HW04-09), which has a higher K-feldspar content and is a monzonite (Fig. 3). Compared to the monzodiorite unit, the xenoliths are finer grained and tend to have a higher proportion of mafic minerals.

The syenite dykes in monzodiorite on Green Rock consist mostly of microcline and plagioclase with minor quartz, and sparse biotite, hornblende, and opaque minerals. As a whole, the rock has allotriomorphic inequigranular texture. Plagioclase occurs as smaller, equigranular crystals along grain boundaries of larger K-feldspar grains. Irregular patches of coarse-grained K-feldspar are also present. The mafic dykes are gabbroic, with fine-grained intergranular texture of plagioclase and mainly altered pyroxene.

Magnetic susceptibility was measured in the field using a KT-9 Kappameter (manufactured by Geoexploranium Ltd.). Between 4 and 10 readings were taken at each of about 25 out-

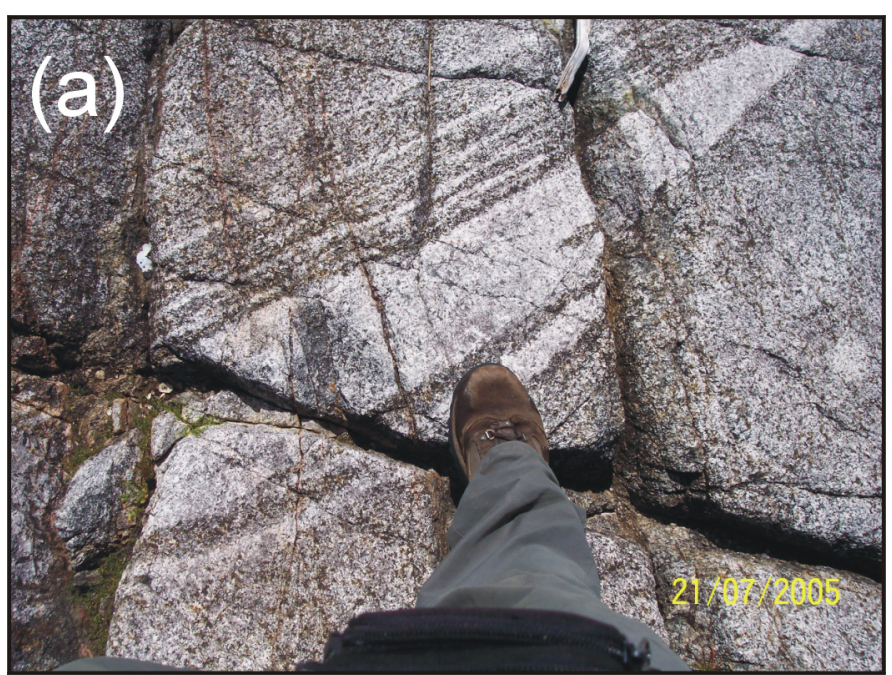

(b)

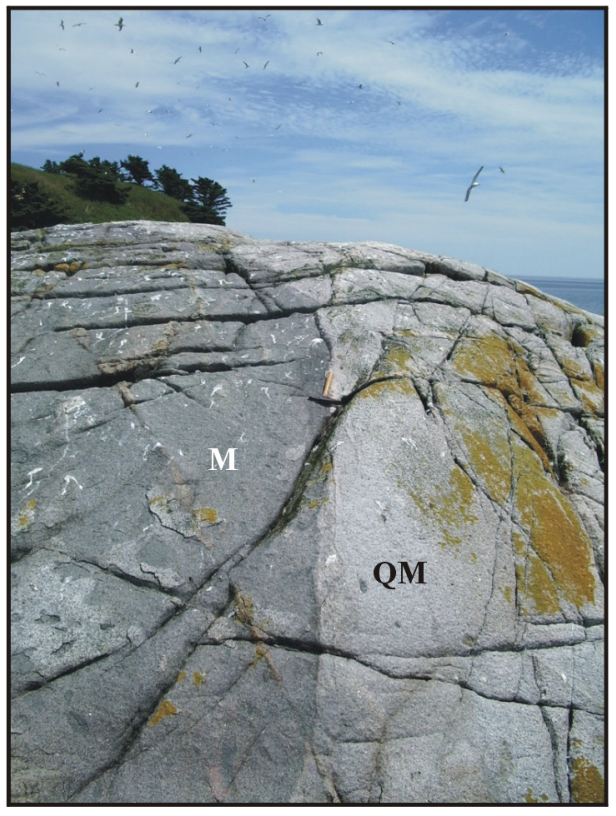

Fig. 4 (a) Outcrop of monzodiorite showing cumulate layering on the northern shore of East Wolf Island. (b) Monzodiorite dyke $(M)$ in quartz monzonite $(\mathrm{QM})$, western shore of Spruce Island.

crops around the islands (Wolzczanski 2006). Average readings ranged from lows of less than 1 to a high of 19 , but averaged about $7.0 \times 10^{-3} \mathrm{SI}$ units. The xenoliths generally gave lower values than their host rocks. One mafic dyke yielded a value of 12.3. These readings are moderate to high in comparison to other rock units in southern New Brunswick (King and Barr 2004) and are consistent with the pluton being the cause of the positive aeromagnetic anomaly in the area of The Wolves (Geological Survey of Canada 1965a, b).

\section{Major- and Trace-Element Geochemistry}

Whole-rock chemical data were obtained for thirty-two samples, focusing on the main monzodiorite unit (Table 1). Six of 

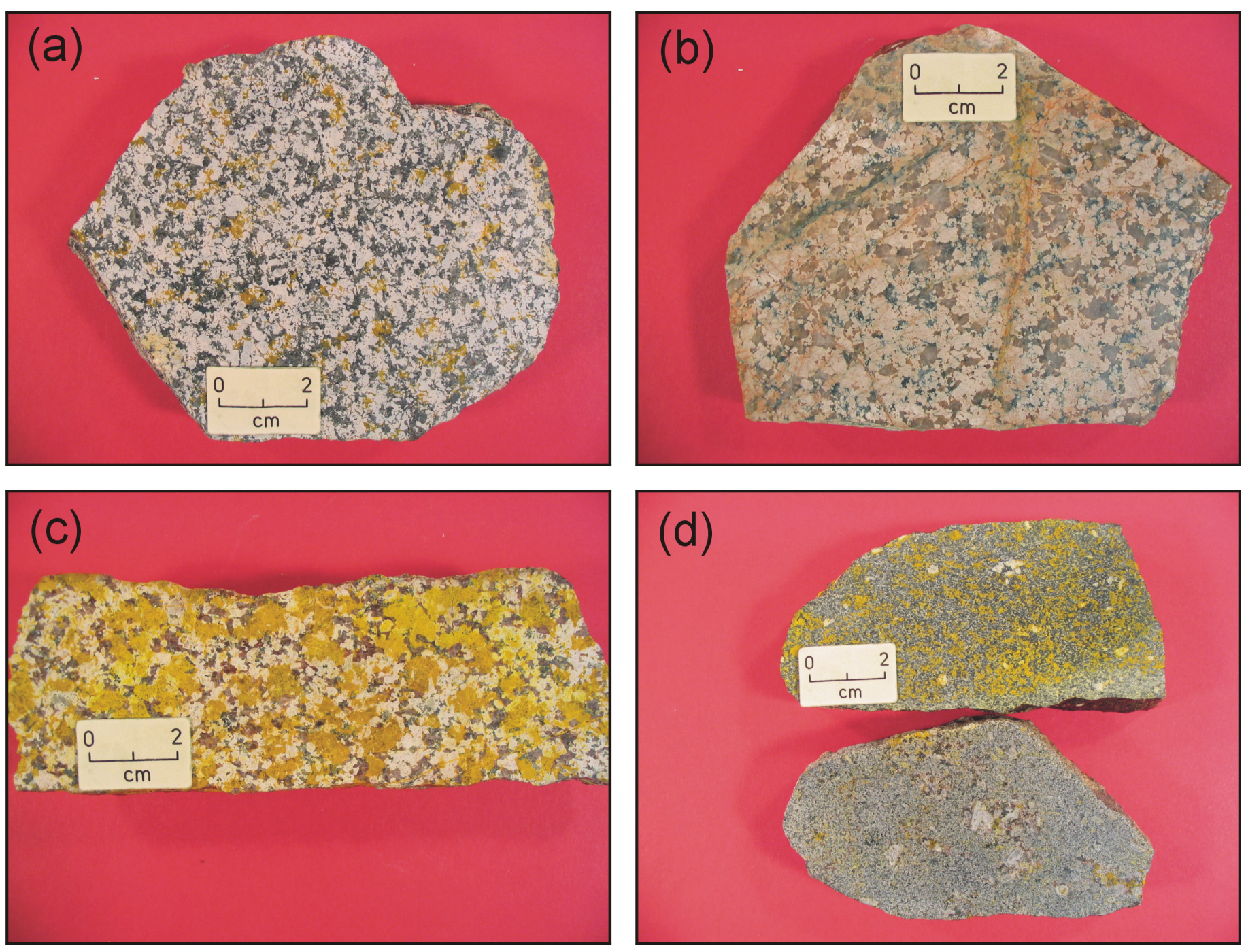

Fig. 5 Hand specimen slabs of representative samples, etched and stained for K-feldspar (yellow) using the technique of Hutchinson (1974). (a) Monzodiorite (sample HW05-31). (b) Tonalite (sample HW05-19). (c) Quartz monzonite (sample HW042). (d) Xenoliths (samples HW04-9 (top) and HW04-3 (bottom)).

those samples were analyzed also for rare-earth elements (Table 2). The silica concentrations in the twenty analyzed monzodiorite unit samples range from $47.6 \%$ to $59.6 \%$ (average $54.5 \%$ ), whereas the five tonalite and two quartz monzonite samples have higher $\mathrm{SiO}_{2}$ (average $69.6 \%$ and $69.0 \%$, respectively). A silica gap of about $6 \%$ separates the most silicic monzodiorite sample from the least silicic tonalite sample. The five dioritic xenolith samples have $\mathrm{SiO}_{2}$ contents ranging from $49.2 \%$ to $54.7 \%$, overlapping those in the low- $\mathrm{SiO}_{2}$ monzodiorite unit samples.

Major element oxide data from both monzodiorite and xenolith samples show scatter but $\mathrm{TiO}_{2}, \mathrm{Fe}_{2} \mathrm{O}_{3}{ }^{\mathrm{t}}, \mathrm{MnO}, \mathrm{MgO}, \mathrm{CaO}$, and $\mathrm{P}_{2} \mathrm{O}_{5}$ generally have negative correlation with $\mathrm{SiO}_{2}$ whereas $\mathrm{Na}_{2} \mathrm{O}$ tends to show positive correlation and $\mathrm{Al}_{2} \mathrm{O}_{3}$ and $\mathrm{K}_{2} \mathrm{O}$ little correlation with $\mathrm{SiO}_{2}$ (Fig. 7). Trace elements (Fig. 8) show even less well developed trends against $\mathrm{SiO}_{2}$ than the major-element oxides. However, the similarity in compositional varia- tion between the xenoliths and the monzodiorite supports a co-magmatic relationship. The xenoliths may represent earlier formed cumulate material disrupted by subsequent magma movement.

In spite of the poorly developed chemical trends and the silica gap between the monzodiorite and the tonalite and quartz monzonite units, the cumulate-type layering (e.g., Fig. 4a) and textures observed in the monzodiorite unit in particular suggest that crystal fractionation was a major process in magma evolution. Major element oxide variations are consistent with feldspar and mafic mineral fractionation (Fig. 7, 8). Co-variations between $\mathrm{TiO}_{2}$ and $\mathrm{Fe}_{2} \mathrm{O}_{3}$ (Fig. 9a) and $\mathrm{V}-\mathrm{Fe}_{2} \mathrm{O}_{3}$ (Fig. $9 \mathrm{~b}$ ) suggest that fractionation of Ti- and V-bearing biotite and magnetite may have produced those trends. Microprobe analyses indicate $\mathrm{TiO}_{2}$ contents up to 3-4 \% in biotite in the monzodiorite unit (Wolzcanski 2006). Strong correlation between $\mathrm{P}_{2} \mathrm{O}_{5}$ and $\mathrm{TiO}_{2}$ (Fig. $9 \mathrm{c}$ ), as well as $\mathrm{P}_{2} \mathrm{O}_{5}$ 

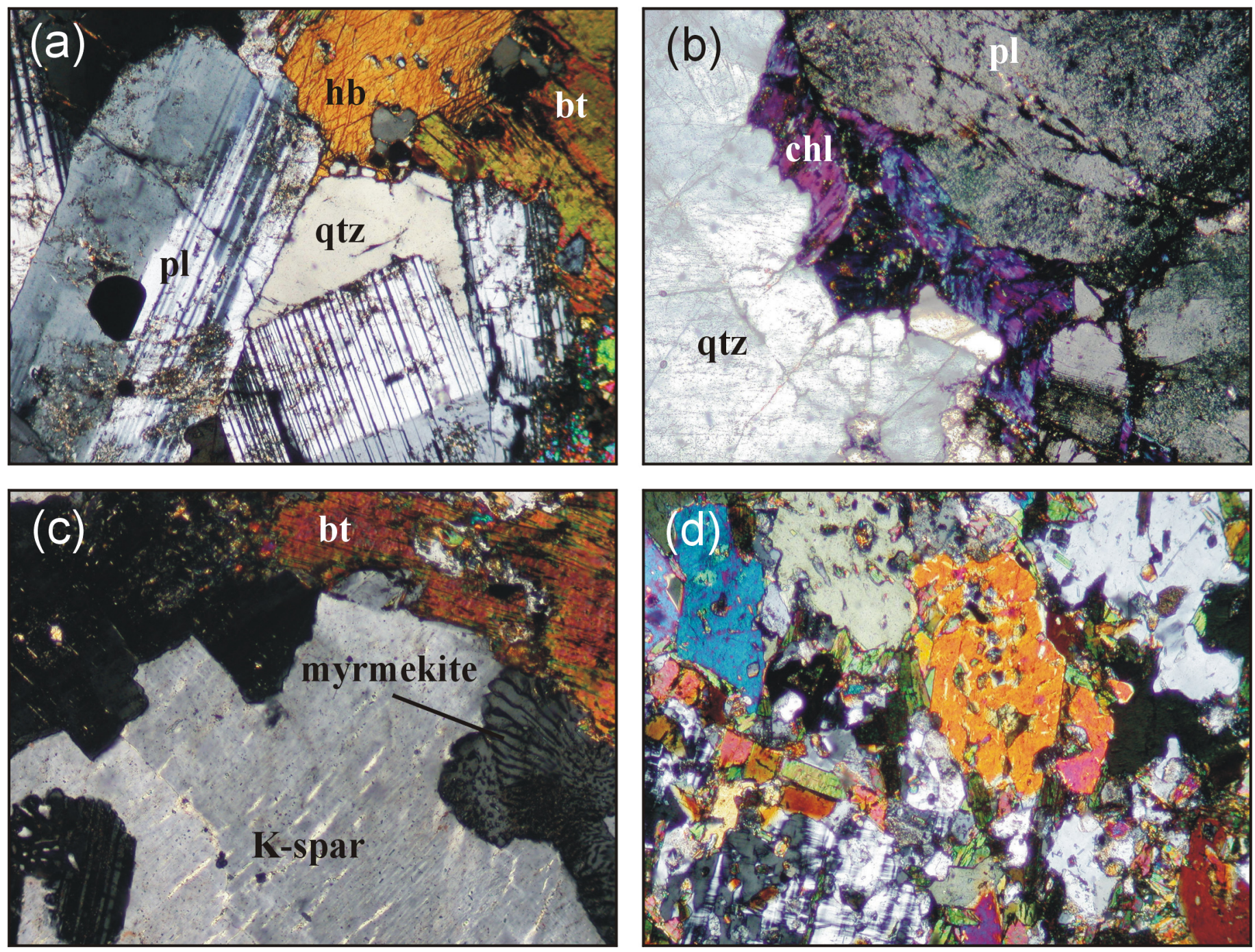

Fig. 6 Photomicrographs of typical samples in thin section under crossed polars. Field of view is about $1 \mathrm{~mm}$ wide. (a) Monzodiorite (sample HW05-28). (b) Tonalite (sample HW05-19). (c) Quartz monzonite (sample HW04-2). (d) Xenolith (HW04-9). Abbreviations: bt, biotite; chl, chlorite ; hb, hornblende; K-spar, potassium feldspar; pl, plagioclase; qtz, quartz.

and $\mathrm{Zr}$ (Fig. 9d), suggest that other accessory phases (titanite, apatite, and zircon) were also involved, perhaps as inclusions in the fractionating biotite. All of these accessory minerals are relatively abundant in the monzodiorite and rare or absent in the tonalite and quartz monzonite samples.

Samples show a calc-alkalic trend on the AFM diagram(Fig. 10a), consistent with the biotite compositions noted above. Although commonly used tectonic setting discrimination diagrams are probably not reliable for these cumulate rocks, a multi-element spider diagram, normalized to N-MORB, reveals that samples from The Wolves Pluton have depletions in $\mathrm{Ta}, \mathrm{Nb}, \mathrm{P}$ and Ti (Fig. 10b), all characteristics of origin in a subduction zone setting.

\section{Rare-Earth Element Data}

All six samples analyzed for rare-earth elements (REE) (Table 2) show light-REE enrichment (Fig. 11). The three mon- zodiorite samples show similar patterns of enrichment in light REE and a steady decrease in middle REE, with a low, flat, heavy REE pattern. One monzodiorite sample (NB00-39A) shows a slight negative Eu anomaly, indicative of feldspar fractionation, and a flatter REE pattern that crosses the patterns of the other monzodiorite samples. The pattern for the xenolith sample is similar to those for the monzodiorite samples, consistent with a co-magmatic relationship as indicated by the petrographic and other chemical data. Such REE patterns are like those derived from melting of mafic sources (e.g., Hanson 1980).

The quartz monzonite sample shows a steeper REE pattern, and more depletion in the heavy REE, consistent with having experienced more mafic and accessory mineral fractionation. This saddle-shaped heavy REE pattern is much more pronounced in the tonalite sample, which has lower REE than any of the other samples. It also displays a positive Eu anomaly, consistent with plagioclase accumulation in the rock. Crystal fractionation models (e.g., Hanson 1980; Gromet and Silver 


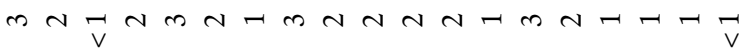

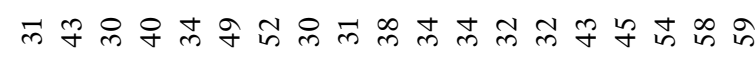

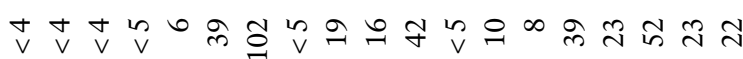

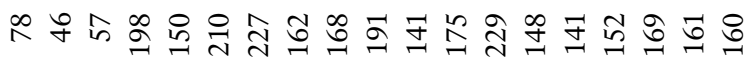

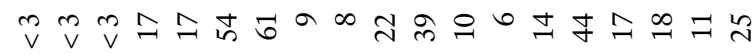

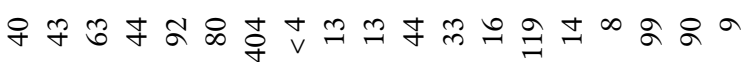

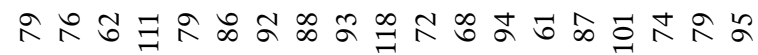

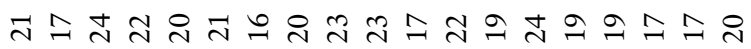

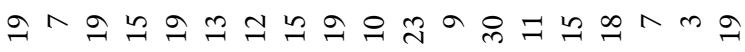

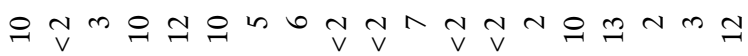

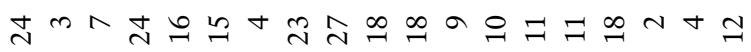

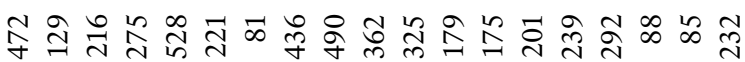

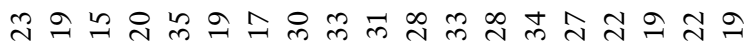

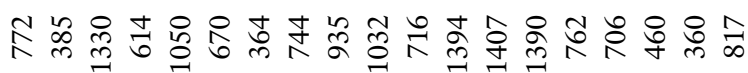

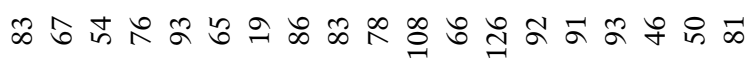

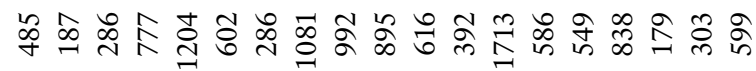

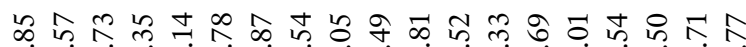

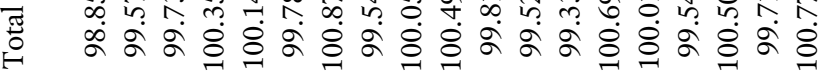

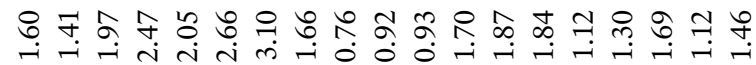

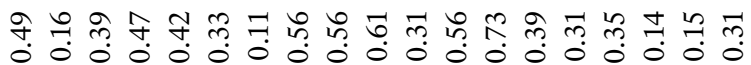

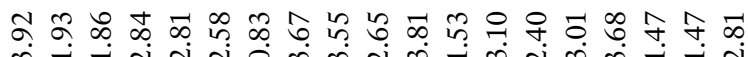

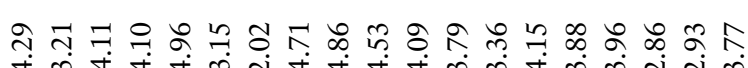

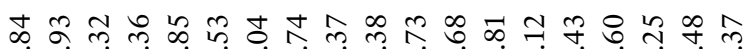

定考

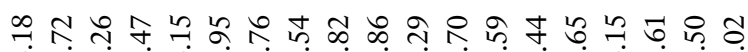

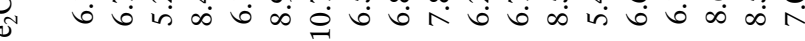

乎年

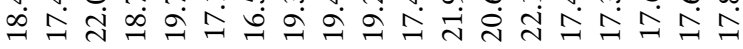
లి भे 0 ○े

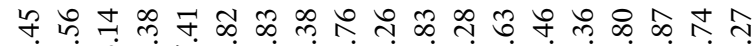

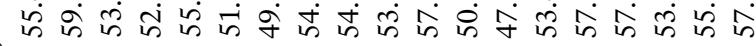
$\approx$ 놇

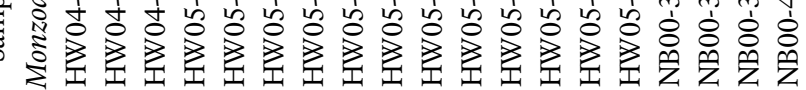

$n+4+\cos \theta$ 우 앙ำ

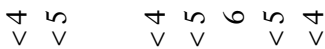
누 in

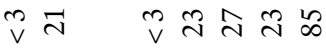

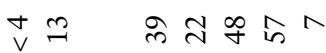

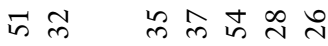

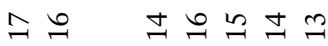

ํㅠ

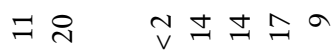

in $\stackrel{v}{\sim} \quad \vec{v} \wedge+0-$

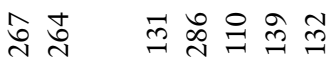

$\exists \bar{m}$

约 $\infty$

?ำㄴ

กิำ

tै

\&̊으

ลิ

$\rightarrow 2$

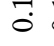

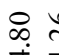

도

શิ

ผ

ㄴํำ

च ल

궘

ชื่ลู

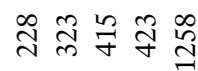

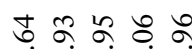
ठे ने ठे

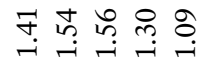

$\begin{array}{ccccc}\infty & 0 & 0 & 0 & 1 \\ 0 & \ddots & 0 & 0 & 0 \\ 0 & 0 & 0 & 0 & 0\end{array}$

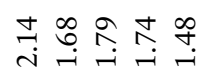

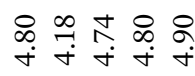

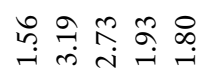

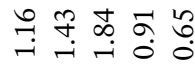

ํํㅇㅇㅇㅇํㅇ ํํㅇ ?

$\infty \stackrel{\infty}{1}$

i

in

in

I

$\approx+\infty$ ปิ ㅇํㅇ

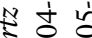
है 요 ఈ్ㅠ 4 म +4

ข ப் ف볌 กิ กำ तं क्ष สุำ

T)

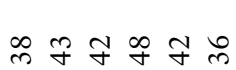
궁웜국 ชิ

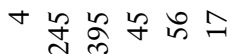

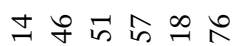

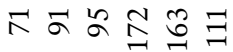

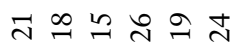
mom

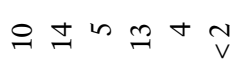
$\stackrel{\infty}{\sim} \underset{\sim}{\sim} \stackrel{\infty}{\sim}$ 的

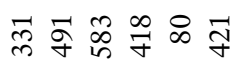
तี

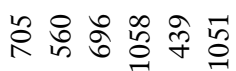
ஊ

认ิ

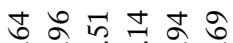
ळু

‡.

กี f

규아 궁 in कित ळ $\vec{\infty}$ त्र

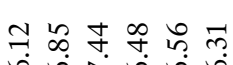
$\infty \sigma \widetilde{\leftrightarrow}$ ले $\sigma$ 的的分

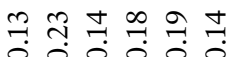

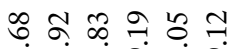
बरतब

के 둄 $\stackrel{\infty}{\rightarrow} \stackrel{\infty}{\rightarrow}$

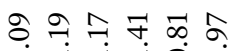

ำ

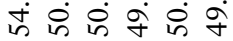

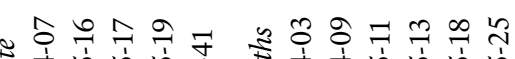

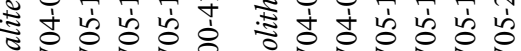

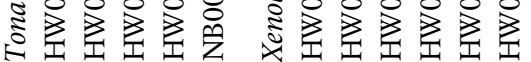



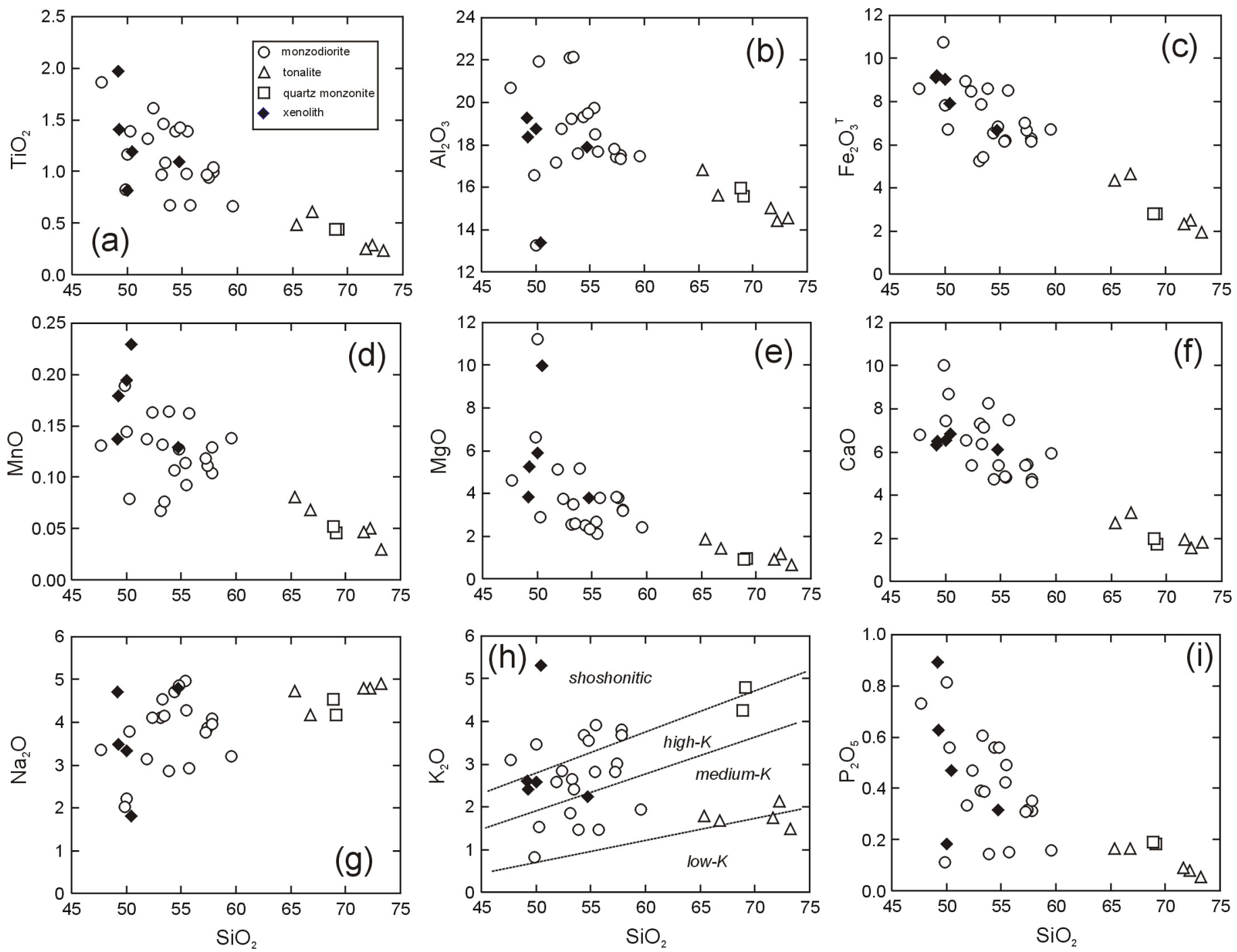

Fig. 7 Plots of major element oxides against $\mathrm{SiO}_{2}$ (all in weight \%) to illustrate chemical variation in The Wolves Pluton. Chemical data are from Table 1. Fields in (h) are after Middlemost (1975).

1987) show that fractionation of hornblende is a likely cause of saddle-shaped heavy REE patterns, although accessory mineral removal is also needed to lower the total REE abundance to that seen in the tonalite sample.

\section{U-Pb Dating}

U-Pb zircon dating of monzodiorite sample NB00-40 (Fig. 2) was done at the University of North Carolina-Chapel Hill Isotope Geochemistry Laboratory. Zircon grains were separated from the ca. $25 \mathrm{~kg}$ sample using standard techniques, and hand picked under a binocular microscope in order to select groups of grains that were similar in morphology and as clear, crack-free, and inclusion-free as possible. All zircon fractions were highly abraded. Detailed analytical procedures are described in Miller et al. (2006). Data reduction followed Ludwig (1989) using the unpublished program PbMacDat
(D. Coleman, University of North Carolina) with the plotting and regression algorithms of Ludwig (1990; 1998). Data are presented in Table 3 and on concordia diagram (Fig. 12) at the 2-sigma uncertainty level.

Zircon grains separated from sample NB00-40 were mainly large prisms with relatively high $\mathrm{U}$ and radiogenic $\mathrm{Pb}$ concentrations, allowing for the analysis of single- and twograin fractions. One analyzed grain was brown and slightly metamict. This grain contained very high $U$ and radiogenic $\mathrm{Pb}$ concentrations and is highly discordant due to geologically recent Pb-loss (Fig. 12). Seven other fractions consisted of single prismatic grains, or fragments of prismatic grains. One concordant analysis is slightly older than the rest; its exclusion from the regression line reduces the uncertainty but does not significantly affect the age. The upper intercept of a regression line that includes all eight analyses is $436.4 \pm 1.2 \mathrm{Ma}$, which we interpret as the time of crystallization of the monzodiorite. 

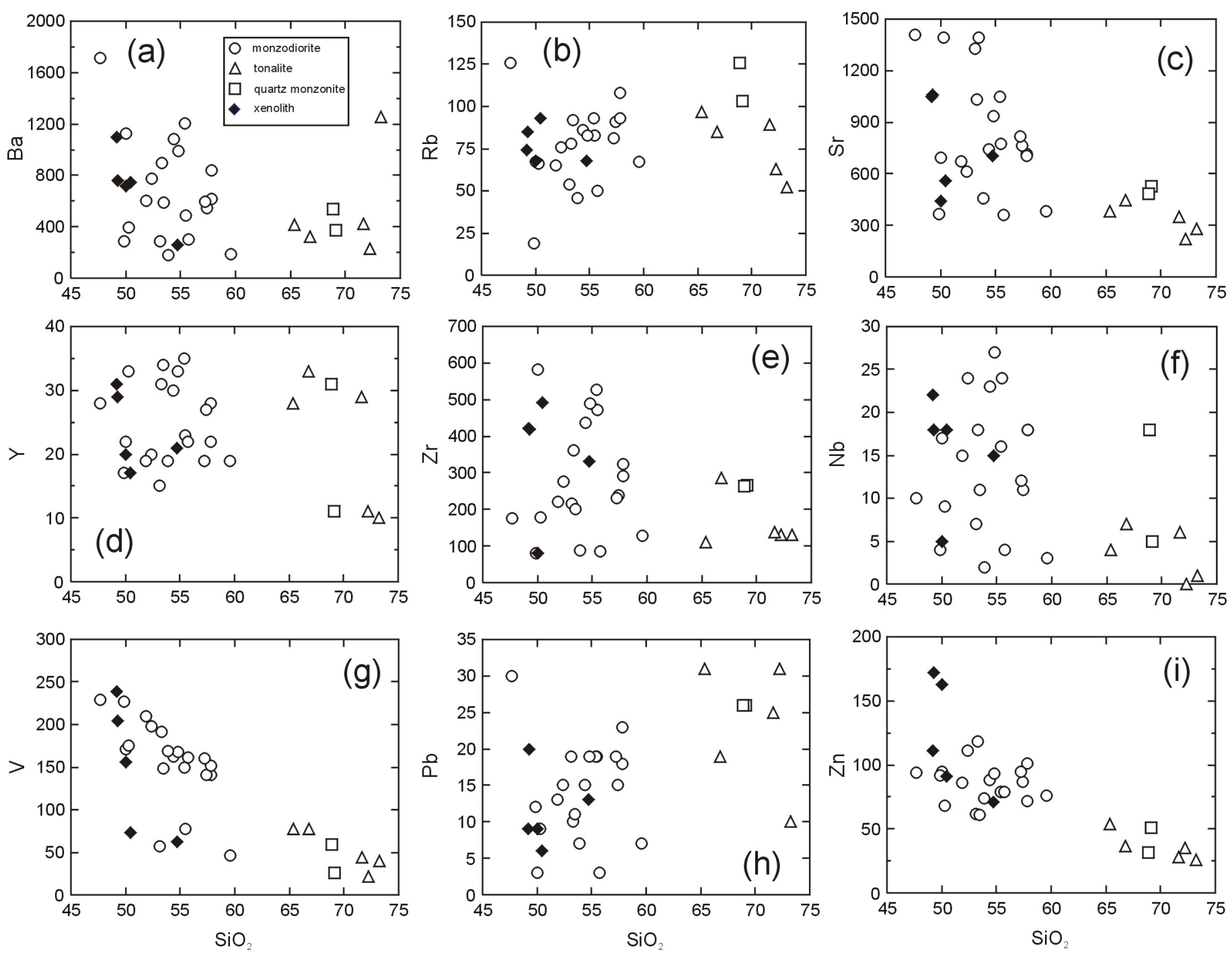

Fig. 8 Plots of (a) Ba, (b) $\mathrm{Rb},(\mathrm{c}) \mathrm{Sr}$, (d) $\mathrm{Y},(\mathrm{e}) \mathrm{Zr}$, (f) $\mathrm{Nb},(\mathrm{g}) \mathrm{V}$, (h) $\mathrm{Pb}$, and (i) $\mathrm{Zn}$ (in ppm) against $\mathrm{SiO}_{2}$ (in weight \%) to illustrate chemical variation in The Wolves Pluton.

\section{Sm-Nd Isotopic Data}

Samarium and Nd isotopic data were obtained for three samples representing the monzodiorite, tonalite, and quartz monzonite units (Table 4). The $\varepsilon_{\mathrm{Nd}}$ values (calculated to the $\mathrm{U}-\mathrm{Pb}$ age, $436 \mathrm{Ma})$ are closely clustered at $3.8,3.6$, and 2.7 , with depleted mantle model ages between 671 and $779 \mathrm{Ma}$. The similarity in $\varepsilon_{\mathrm{Nd}}$ is consistent with a co-magmatic origin for the three granitoid units on The Wolves. The parent magma may have been a mantle-derived melt that experienced some crustal contamination to lower the $\varepsilon_{\mathrm{Nd}}$ from typical depleted mantle values of ca. 7 (Fig. 13). Alternatively, the magma may have been derived by partial melting of juvenile, mafic mantlederived rocks in the lower crust. The latter origin is more consistent with the REE patterns described above.

\section{DISCUSSION}

The Wolves are on strike with the Brookville terrane (Fig. 1), and the granitoid rocks exposed on these islands are petrologically similar to some of the abundant granitoid rocks of the Brookville terrane (Barr et al. 2001; White et al. 2002). However, the petrological similarities are likely the result of the plutons having formed in similar subduction zone settings, because the Brookville terrane plutons have ages between 555 and $527 \mathrm{Ma}$ (White et al.2002), and hence can have no direct link with the $436 \mathrm{Ma}$ rocks in The Wolves Pluton. If The Wolves Pluton is located in the Brookville terrane, then it is the only Silurian pluton known in that belt, which has been well studied in the onshore part (White et al. 2002). Furthermore, plutons in the Brookville terrane, even those of Devonian age, have mainly negative or only slightly positive epsilon $\mathrm{Nd}$ values, 


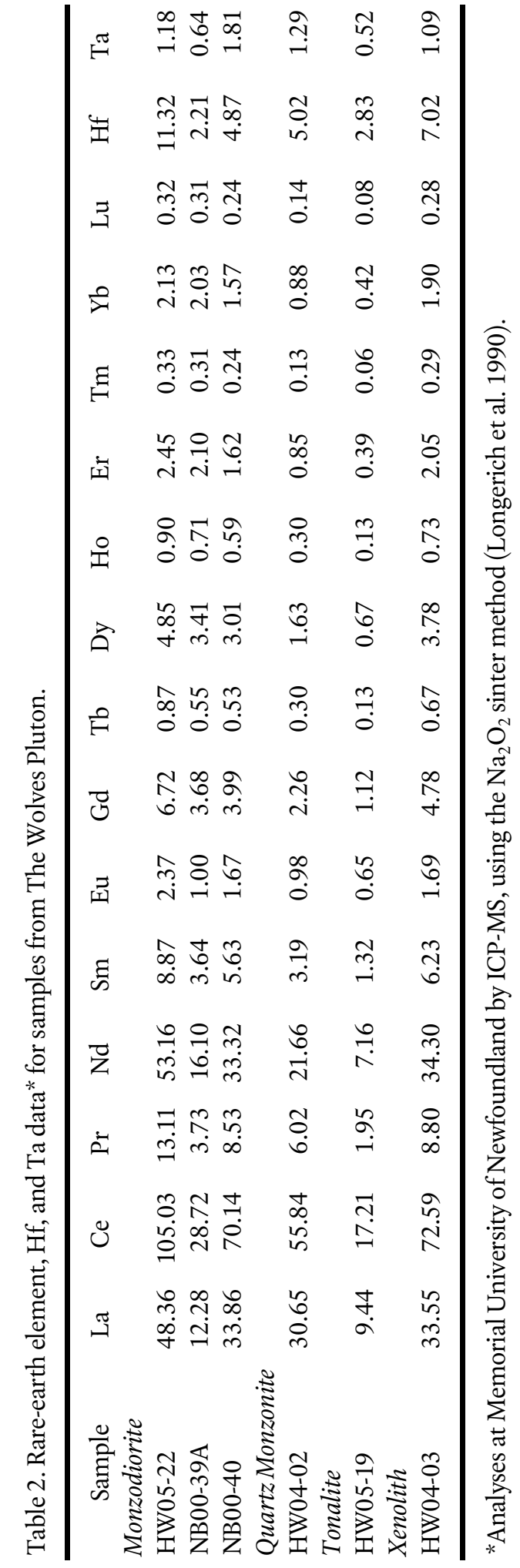

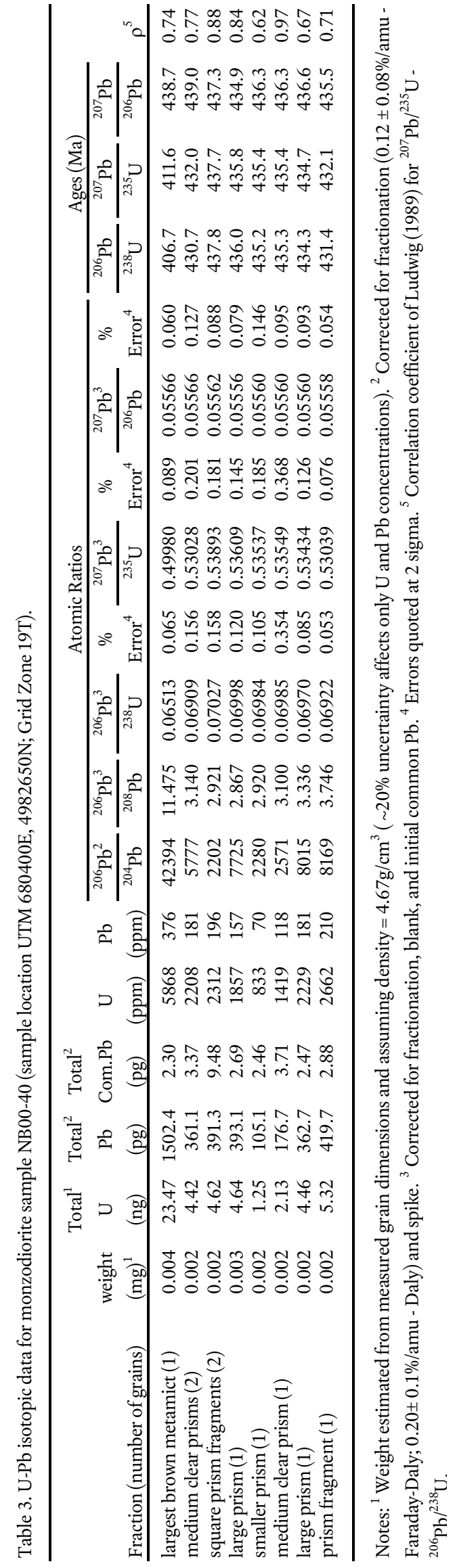



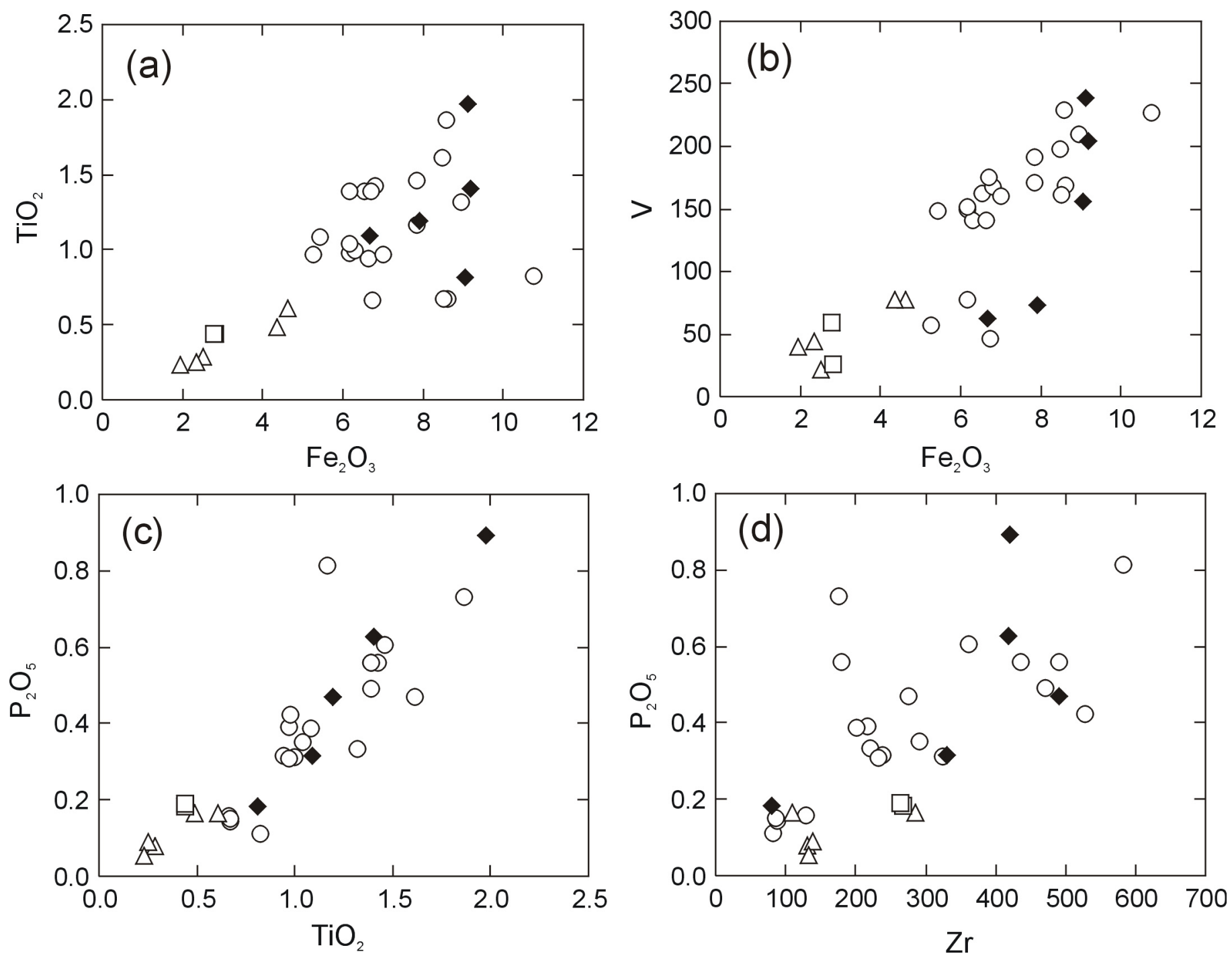

Fig. 9 Plots of $(\mathrm{a}) \mathrm{TiO}_{2}-\mathrm{Fe}_{2} \mathrm{O}_{3},(\mathrm{~b}) \mathrm{V}-\mathrm{Fe}_{2} \mathrm{O}_{3},(\mathrm{c}) \mathrm{P}_{2} \mathrm{O}_{5}-\mathrm{TiO}_{2}$, and (d) $\mathrm{P}_{2} \mathrm{O}_{5}-\mathrm{Zr}$ to illustrate chemical trends in The Wolves Pluton.

and hence the terrane seems unlikely to generate rocks with the positive epsilon Nd values like those measured in samples from The Wolves Pluton (Fig. 13).

The Caledonia terrane in southern New Brunswick, part of Avalonia (Hibbard et al. 2006), also includes abundant granitoid rocks (Barr and White 1999; Barr et al. 2003b). However, their ages of ca. 620 and ca. $550 \mathrm{Ma}$ are too old to be directly related to The Wolves Pluton. No plutons with ages of ca. $436 \mathrm{Ma}$ are known in Caledonia terrane, or in the Cobequid Highlands of northern mainland Nova Scotia, which is also part of Avalonia (e.g., Pe-Piper and Piper 2002). Interpretations of seismic reflection profiles in the Bay of Fundy in the vicinity of The Wolves place the islands well to the north of the normal fault system that separates Meguma terrane rocks from Avalonia (e.g., Wade et al. 1996; Keen et al. 1991). In any case, the age and petrological characteristics of The Wolves Pluton are not compatible with an origin in crust of the Meguma terrane, which has yielded mainly peraluminous granitoid rocks (e.g., Clarke et al. 1997).
In terms of age, The Wolves Pluton is a good match with volcanic and plutonic rocks of the Kingston terrane, which have yielded ages of 442-435 Ma (Barr et al. 2002). This narrow fault-bounded belt of Silurian calc-alkaline rocks has been interpreted to represent a continental-margin arc terrane formed on the Ganderian New River terrane. According to Barr et al. (2002), subduction in the Kingston arc culminated in a collision between the New River terrane and the Brookville terrane, and an ensuing extensional setting in the Late Silurian, related to transpressive motion, resulted in the emplacement of abundant tholeiitic mafic dykes.

Although of similar age, the Kingston terrane rocks are not similar petrologically to The Wolves Pluton. Plutonic rocks in the Kingston terrane are mainly fine-grained aphyric to porphyritic granite with granophyric textures and other features indicative of high-level emplacement, and they are intimately associated with co-magmatic, mainly felsic, pyroclastic rocks (Barr et al. 2002). These rocks are markedly different from the medium- to coarse-grained rocks on The Wolves, none 


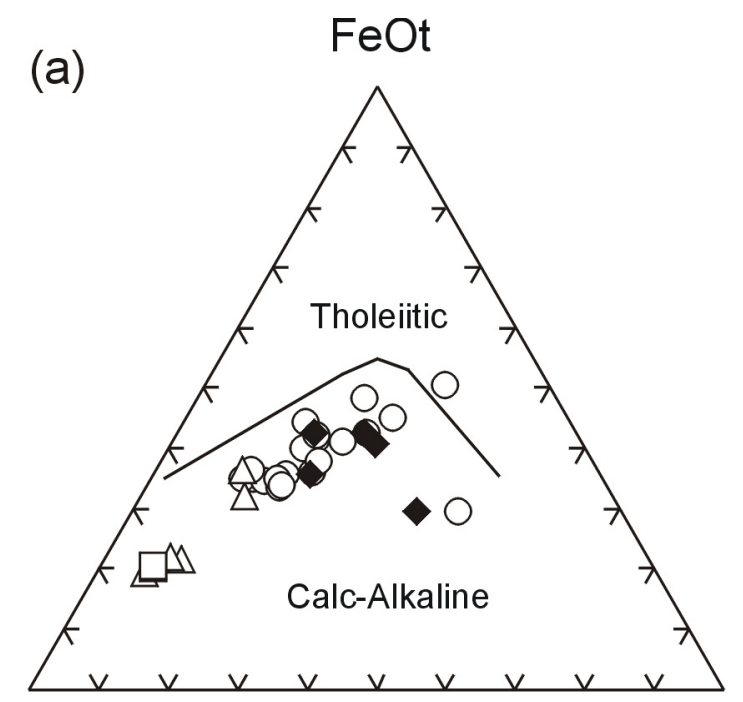

$\mathrm{Na}_{2} \mathrm{O}+\mathrm{K}_{2} \mathrm{O}$

(b)

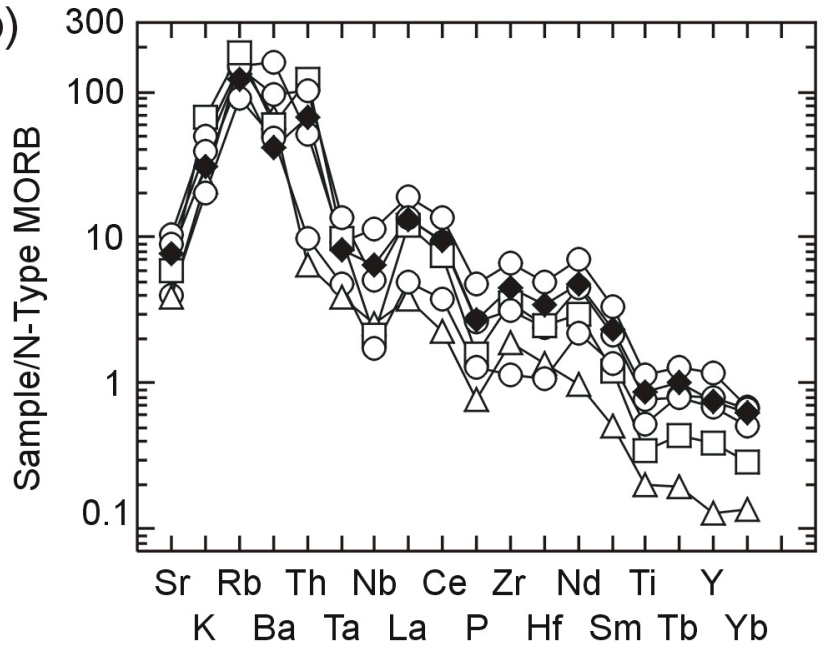

Fig. 10 (a) AFM ternary diagram (tholeiitic-calc-alkaline dividing line from Irvine and Baragar 1971), and (b) multielement variation diagram for selected samples, normalized against N-MORB (normalizing values from Sun and McDonough 1989).

of which is granite sensu stricto. However, minor mediumto coarse-grained monzodiorite and diorite occur near the margins of two of the plutons in the Kingston terrane (Barr et al. 2002), and it is possible that the granitoid rocks on The Wolves represent deeper parts of the Kingston arc. If so, The Wolves escaped much of the pervasive mafic dyke-emplacement event that characterizes the Kingston terrane, as well as subsequent deformation and accompanying amphibolite-facies metamorphism (Barr et al. 2002). However, evidence for that metamorphic event is less pronounced in the southwestern part of the terrane on Campobello Island (McLeod and Rast 1988; McLeod et al. 2001). Samples from both the Kingston

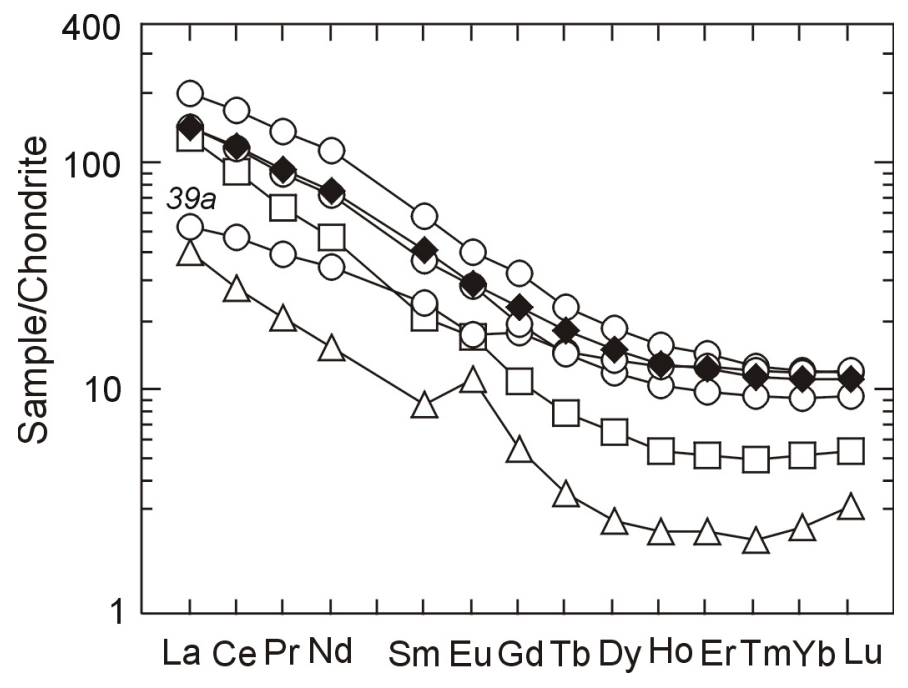

Fig. 11 Chondrite-normalized REE diagrams samples from The Wolves Pluton. Data are from Table 2. Chondrite-normalizing values are from Sun and McDonough (1989).

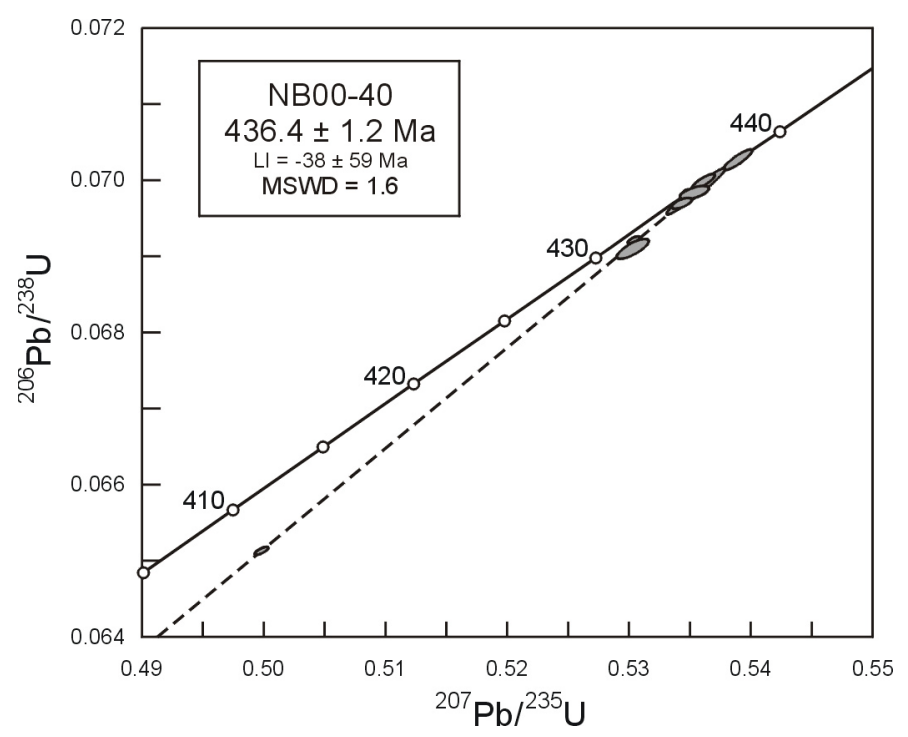

Fig. 12 Concordia diagram for dated sample Concordia diagrams for dated sample NB00-40. LI is the lower intercept of the regression line with Concordia. Data are from Table 3.

terrane and The Wolves Pluton are characterized by similar positive $\varepsilon_{\mathrm{Nd}}$ values between 2.5 and 4 (Fig. 13). Furthermore, a prominent magnetic signature is characteristic of the Kingston terrane (e.g., King and Barr 2004), an attribute also associated with The Wolves.

Volcanic rocks of early Silurian age are also present in the more inboard Mascarene terrane in southern New Brunswick (Fyffe et al. 1999; Miller and Fyffe 2002). However, they are mainly rift-related rhyolite and no plutonic rocks of similar age are known in the area; their distance from The Wolves also makes a direct link unlikely. Plutonic rocks make up much of the Coastal Maine Magmatic Province and continue into south- 


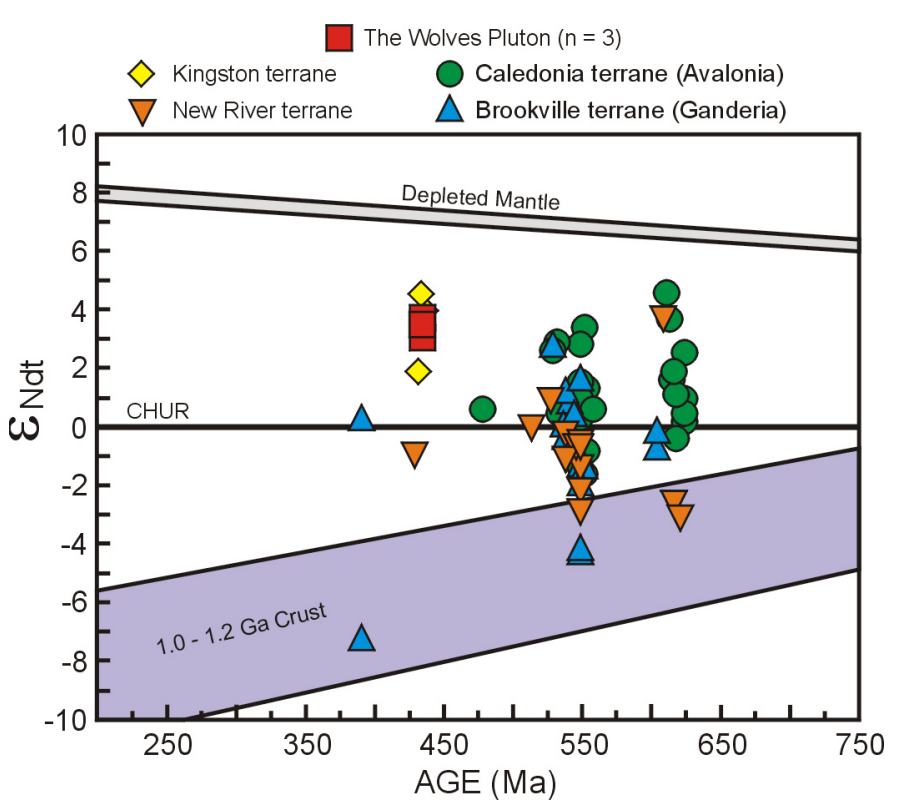

Fig. 13 Epsilon Nd data (calculated at $436 \mathrm{Ma}$ ) plotted against unit age. Data are from Samson et al. (2000), Barr et al. (2003b), and Table 4.

ern New Brunswick as the Saint George Batholith (Fig. 1), but they are Late Silurian to Devonian in age (Hogan and Sinha 1989; McLaughlin et al. 2003). The Early Silurian (436 Ma) age of The Wolves Pluton precludes a direct link with those voluminous plutons, the oldest of which seems to be ca. $425 \mathrm{Ma}$.

Looking farther offshore for possible correlations, Grand Manan Island to the south of The Wolves consists mainly of Mesozoic rocks. Plutonic rocks are only a minor component, and all that are exposed have been dated and yielded Neoproterozoic to early Cambrian ages (Miller et al. in press). Associated volcanic and sedimentary rocks have a similar age range, and it is not clear that any Silurian rocks are present on Grand Manan Island.

In summary, granitoid rocks on The Wolves appear to be geological orphans that have no directly correlative rocks in adjacent land areas. Based on the arguments presented above, the best correlation seems to be with the Kingston terrane. Assignment of The Wolves Pluton to the Kingston terrane implies apparent sinistral offset of the terrane to the southeast by $5-10 \mathrm{~km}$ relative to its position on the mainland (Fig. 14). Magnetic coverage in the critical areas is limited, but reveals some evidence for an east-trending structure that could be a fault (Fig. 14). This fault may also offset other terranebounding faults (Belleisle, Kennebecasis, Caledonia, CobequidChedabucto), and could be one of a series of faults that offset southern New Brunswick terranes and terrane boundaries outboard to beyond Grand Manan Island (e.g., McCutcheon and Robinson 1987; Hibbard et al. 2006). This interpretation is consistent with the proposed correlation of rocks on Grand Manan Island with the New River and Mascarene terranes (Miller et al. in press). However, it is difficult to reconcile with the apparent continuity of the Kingston terrane through 


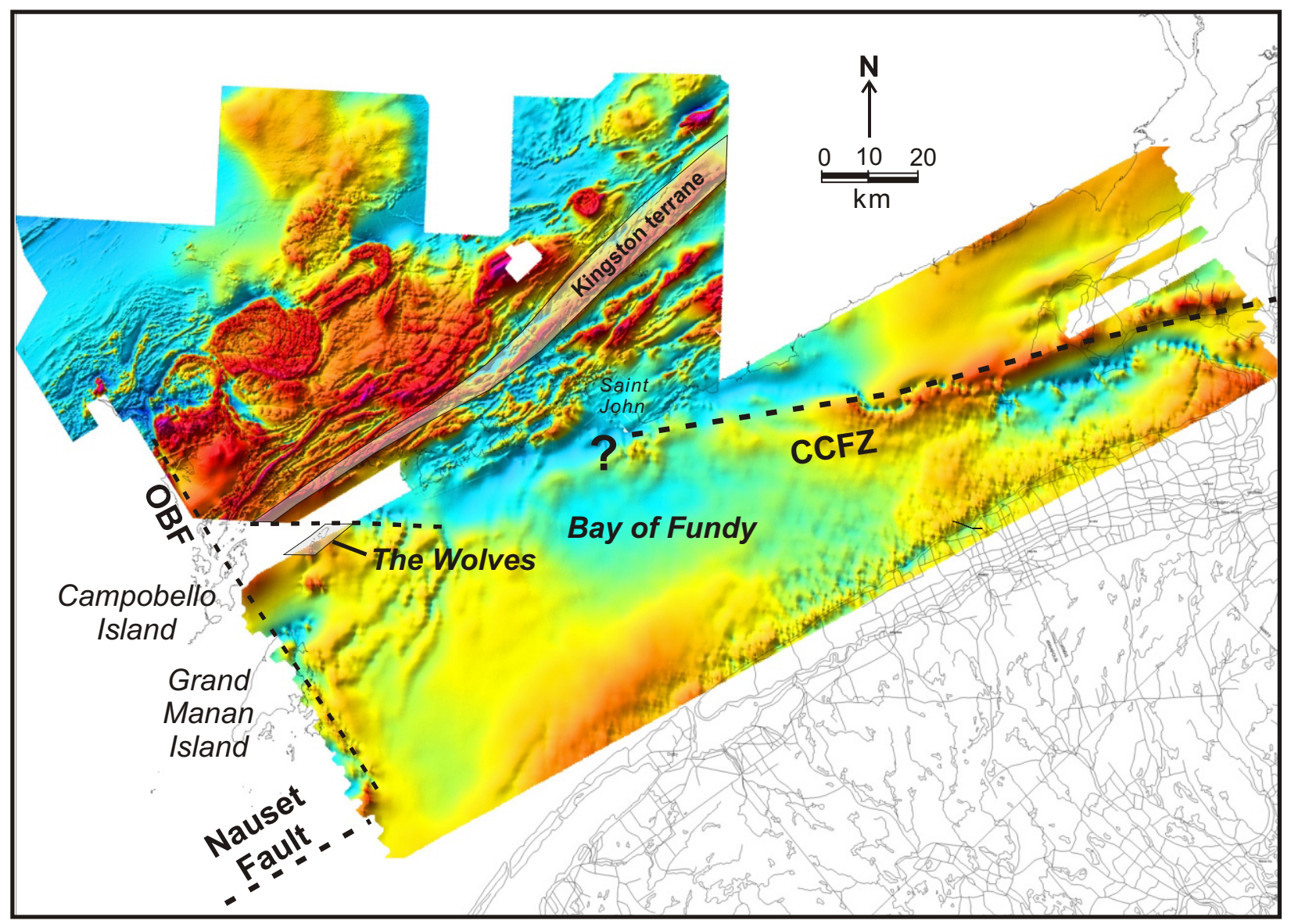

Fig. 14 Magnetic total field map of data from onshore and offshore magnetic surveys in the Bay of Fundy area, as compiled by M.S. King (unpublished data, 2005). The area shown is approximately the same as in Figure 1. The postulated east-trending fault between The Wolves and the onshore Kingston terrane (shaded) is indicated by the black dashed line north of The Wolves. Abbreviations: CCFZ, Cobequid-Chedabucto Fault Zone; OBF, Oak Bay Fault. The Nauset Fault marks the inferred boundary between Avalonia and Meguma (Hutchinson et al. 1988; Hibbard et al. 2006).

Campobello Island and into Maine (McLeod and Rast 1988; McLeod et al. 2001). The geological enigmas associated with these terrane boundaries might be resolved by more detailed aeromagnetic data in the western Bay of Fundy between The Wolves, Grand Manan Island, and the mainland.

\section{CONCLUSIONS}

The Wolves Pluton is composed mainly of monzodiorite gradational to diorite, quartz diorite, and quartz monzodiorite, with minor units of tonalite and quartz monzonite. Dioritic to monzodioritic xenoliths are mineralogically and chemically similar to the monzodiorite unit, and are interpreted to represent a deeper, less evolved part of the pluton. The Wolves Pluton has relatively high magnetic susceptibility and likely coincides in extent with a positive magnetic anomaly, suggesting that the pluton has an area of about $75 \mathrm{~km}^{2}$. The pluton is calc-alkalic and likely formed in a volcanic-arc setting. It may be a deeper part of the Silurian Kingston arc, offset a few kilome- ters by a fault trending approximately east-west with apparent sinistral offset. Other terranes and terrane-bounding faults in the western part of the Bay of Fundy may be similarly offset, as part of a series of offsets stepping southern New Brunswick terranes outboard to Grand Manan Island and beyond.

\section{ACKNOWLEDGEMENTS}

This paper is based on a B.Sc. Honours thesis by the senior author. Her work was funded by two Natural Sciences and Engineering Research Council Undergraduate Summer Research awards $(2004,2005)$, and by a Natural Sciences and Engineering Research Council Discovery Grant to S. M. Barr. We thank Ozzie in Beaver Harbour for providing transportation to the islands and Cameron Bartsch and Jose Texidor-Carlsson for assisting with fieldwork. We thank journal reviewers L.R. Fyffe and C.E. White, as well as editor R.A. Fensome, for their constructive suggestions which led to improvements in the manuscript. 


\section{REFERENCES}

Abdel-Rahman, A. M. 1992. Nature of biotites from alkaline, calc-alkaline and peraluminous magmas. Journal of Petrology, 35, pp. 525-541.

Alcock, F. J. 1948. Campobello, New Brunswick Sheet. Geological Survey of Canada Map 964A, scale 1:63,000.

BARr, S. M., AND White, C. E. 1999. Field relations, petrology and structure of Neoproterozoic rocks in the Caledonian Highlands, southern New Brunswick, Canada. Geological Survey of Canada, Bulletin 530, $101 \mathrm{p}$.

Barr, S. M., White, C. E., And Miller, B. V. 2001. Cambrian granitoid plutons of the Pocologan area and the continuation of the Brookville terrane to the Wolves Islands. In Current Research 2000. Edited by B. M. W. Carroll. New Brunswick Department of Natural Resources and Energy, Minerals and Energy Division, Mineral Resources Report 2001-4, pp. 15-24.

Barr, S. M., White, C. E., And Miller, B. V. 2002. The Kingston terrane, southern New Brunswick, Canada: evidence for a Silurian volcanic arc. Geological Society of America Bulletin, 114, pp. 946-982.

Barr, S. M., Miller, B. U., Fyffe, L. R., And White, C. E. 2003a. New U-Pb Ages from Grand Manan and the Wolves Islands, southern New Brunswick. In Current Research 2002. Edited by B. M.W. Carroll. New Brunswick Departments of Natural Resources, Mineral Rescources Report 2003-4, pp. 13-22.

Barr, S.M., White, C.E., ANd Miller, B.V. 2003b. Age and geochemistry of Late Neoproterozoic and Early Cambrian igneous rocks in southern New Brunswick: similarities and contrasts. Atlantic Geology, 39, pp. 55-73.

Clarke, D.B., MacDonald, M.A., and Tate, M.C. 1997. Late Devonian mafic-felsic magmatism in the Meguma Zone, Nova Scotia. In The nature of magmatism in the Appalachian Orogen. Edited by A.K. Sinah, J.B. Whalen, and J.P. Hogan. Geological Society of America Memoir 191, pp. 107-127.

DePaolo, D.J. 1988. Neodymium isotope geochemistry: an introduction. New York, Springer-Verlag, 187 p.

Fyffe, L. R., Pickerill, R. K., AND Stringer, P. 1999. Stratigraphy, sedimentology and structure of the Oak Bay and Waweig formations, Mascarene Basin: implications for the Paleotectonic evolution of southwestern New Brunswick. Atlantic Geology, 35, pp. 59-84.

Geological Survey of Canada. 1965a. Airborne magnetic survey, Eastport, New Brunswick. Map 7033G, scale 1: 253,440 .

Geological Survey of Canada. 1965b. Airborne magnetic survey, Fredriction, New Brunswick. Map 7037G, scale 1: 253,440.

Gromet, L.P., AND SiLver, L.T. 1987. REE variations across the Peninsular Ranges Batholith: implications for batholithic petrogenesis and crustal growth in magmatic arcs. Journal of Petrology, 28, pp. 75-125.

Hanson, G.N. 1980. Rare earth elements in petrogenetic studies of igneous systems. Annual Reviews of Earth and Planetary Sciences, 8, pp. 371-406.

Hibbard, J.P., van StaAl, C.R., Rankin, D., ANd Williams, H. 2006 Lithotectonic map of the Appalachian orogen (north), Canada-United States of America. Geological Survey of Canada Map 02041A, scale 1:1,500,000.

Hogan, J.P., AND SinHA, A.K. 1989. Compositional variation of plutonism in the Coastal Maine Magmatic Province: mode of origin and tectonic setting. In Studies in Maine geology - igneous and metamorphic geology, Edited by R. D. Tucker and R. G. Marvinney, 4, pp. 1-33.

Hutchinson, C. S. 1974. Laboratory handbook of petrographic techniques. Wiley Interscience, New York, $527 \mathrm{p}$.

Hutchinson, D.R., Klitgord, K.D., Lee, M.W., And Trehu, A.M. 1988. U.S. Geological Survey deep seismic profile across the Gulf of Maine. Geological Society of America Bulletin, 100, pp. 172-184.

Irvine, T.N., AND Baragar, W.R.A. 1971. A guide to the chemical classification of the common volcanic rocks. Canadian Journal of Earth Sciences, 8, pp. 523-548.

Keen, C. E., Kay, W. A., Keppie, J. D., Marillier, F., PePiper, G., and Waldron, J. W. F. 1991. Deep seismic reflection data from the Bay of Fundy and Gulf of Maine: tectonic implications for the northern Appalachians. Canadian Journal of Earth Sciences, 28, pp. 1096-1111.

KING, M. S., AND BARR, S. M. 2004. Magnetic and gravity models across terrane boundaries in southern New Brunswick, Canada. Canadian Journal of Earth Sciences, 41, pp. 1027-1047.

LeAKe, B.E., Wooley, A.R., AND 20 others, 1997. Nomenclature of amphiboles: report of the Subcommittee on Amphiboles of the International Mineralogical Association, Commission on New Minerals and Mineral Names. Canadian Mineralogist, 35, pp. 219-246.

Longerich, H., Jenner, G.A., Fryer, B.J., and Jackson, S.E. 1990. Inductively coupled plasma- mass spectrometric analysis of geochemical samples. A critical evaluation on case studies. Chemical Geology, 83, pp. 105-118.

LUDWIG, K.R. 1989. Pb-Dat: A computer program for processing raw $\mathrm{Pb}-\mathrm{U}-\mathrm{Th}$ isotope data. US Geological Survey OpenFile Report 88-557, 34 p.

LUDWIG, K.R. 1990. Isoplot: a plotting and regression program for radiogenic isotopic data. United States Geological Survey, Open File Report 90-91, 39 p.

LuDwIG, K.R. 1998. On the treatment of concordant uranium-lead ages. Geochimica et Cosmochimica Acta, 62, pp. 665-676.

McCutcheon, S. R., And Robinson, P. T. 1987. Geological constraints on the genesis of the Maritimes Basin, Atlantic Canada. In Sedimentary basins and basin forming mechanisms. Edited by C. Beaumont and A. Tankard. Canadian Society of Petroleum Geologists, Memoir 12, pp. 287-297.

McLeod, M. J., AND Rast, N. 1988. Correlations and fault systems in the Passamaquoddy Bay area, southwestern New Brunswick. Atlantic Geology, 24, pp. 289-300. 
McLeod, M. J., Pickerill, R. K., ANd Lux, R. D. 2001. Mafic intrusions on Campobello Island: implications for New Brunswick-Maine correlations. Atlantic Geology, 37, pp. 17-40.

McLaughlin, K.J., Barr, S.M., Hill, M., Thompson, M., Ramezani, J., And Reynolds, P.H. 2003. The Moosehorn Plutonic Suite, southeastern Maine and southwestern New Brunswick: Age, petrochemistry, and tectonic setting. Atlantic Geology, 39, pp. 123-146.

Middlemost, E.A.K. 1975. The basalt clan. Earth Science Reviews, 11, pp. 337-364.

Miller, B.V., AND FyfFe, L.R. 2002. Geochronology of the Letete and Waweig formations, Mascarene Group, southwestern New Brunswick. Atlantic Geology, 38, pp. 29-36.

Miller, B.V., Fetter, A.H., and Stewart, K.G. 2006. Plutonism in three orogenic pulses, Eastern Blue Ridge Province, southern Appalachians. Geological Society of America Bulletin, 118, pp. 171-184.

Miller, B.V., BarR, S.M., and Black, R.S. in press. Neoproterozoic and Cambrian U-Pb (zircon) ages from Grand Manan Island, New Brunswick: implications for stratigraphy and northern Appalachian terrane correlations. Canadian Journal of Earth Sciences.

NANCE, R.D. 1987. Dextral transpression and Late Carboniferous sedimentation in the Fundy Coastal Zone of southern New Brunswick. In Sedimentary basins and basin-forming mechanisms. Edited by C. Beaumont and A.J. Tankard. Canadian Society of Petroleum Geologists, Memoir 12, pp. 363-377.

PARK, A.F. 2001. Carboniferous basement-cover relationships around Maces Bay, southern New Brunswick. In Guidebook to field trips in New Brunswick and eastern Maine. Edited by R.Pickerill, and D. Lentz. New England Intercollegiate Geological Conference, 93rd Annual Meeting, p. C6, 13 p.

Pe-Piper, G., And Piper, D.J.W. 2002. A synopsis of the geology of the Cobequid Highlands, Nova Scotia. Atlantic Geology, 38, pp. 145-160.
Ritchie, P. M. H. 1985. Final Report on the geology of the East Wolf Island Claim Group, Charlotte County, New Brunswick(NTS 21 B/15). Unpublished report prepared for Vernon Rampton. New Brunswick Department of Natural Resources and Energy, Minerals, Policy and Planning Division, Mineral Exploration Report of Work, Assessment File 473123, $10 \mathrm{p}$.

Samson, S. D., Barr, S. M., and White, C. E. 2000. Nd isotopic characteristics of terranes within the Avalon Zone, southern New Brunswick. Canadian Journal of Earth Sciences, 37, pp. 1039-1052.

STEIGER, R.H., AND JÄGER, H. 1977. Subcommission on geochronology: convention on the use of decay constants in geo- and cosmochronology. Earth and Planetary Science Letters, 36, pp. 359-362.

STRECKEISEN, A. 1976. To each plutonic rock its proper name. Earth Sciences Reviews, 12, pp. 1-33.

Sun, S.-S., AND McDonough, W.F. 1989. Chemical and isotopic systematics of oceanic basalts: implications for mantle composition and processes. In Magmatism in the ocean basins. Edited by A.D. Saunders and M.J. Norry. Geological Society, London, pp. 313-345.

Wade, J. A., Brown, D. E., Traverse, A., and Fensome, R. A. 1996. The Triassic-Jurassic Fundy Basin, eastern Canada: regional setting, stratigraphy and hydrocarbon potential. Atlantic Geology, 32, pp. 189-231.

White, C.E., Barr, S.M., Miller, B.V., and Hamilton, M.A. 2002. Granitoid plutons of the Brookville terrane, southern New Brunswick: petrology, age, and tectonic setting. Atlantic Geology, 38, pp. 53-74.

Wolczanski, H. 2006. The Wolves Islands: a missing link in southern New Brunswick geology. Unpublished B.Sc. Thesis, Acadia University, Wolfville, Nova Scotia, 110 p.

Editorial responsibility: Robert A. Fensome 